$\begin{array}{ll} & \text { Etnográfica } \\ \text { etnográfica } & \text { Revista do Centro em Rede de Investigação em }\end{array}$

Antropologia

vol. $18(3) \mid 2014$

Vol. $18(3)$

\title{
"Just bring me a little letter": the flow of things in Cape Verde transnational family relations
}

"Só uma cartinha": o fluxo de coisas nas relações familiares transnacionais em Cabo Verde

\section{Andréa de Souza Lobo}

\section{(2) OpenEdition}

Journals

Electronic version

URL: https://journals.openedition.org/etnografica/3788

DOI: 10.4000/etnografica.3788

ISSN: 2182-2891

\section{Publisher}

Centro em Rede de Investigação em Antropologia

\section{Printed version}

Date of publication: 1 October 2014

Number of pages: 461-480

ISSN: 0873-6561

\section{Electronic reference}

Andréa de Souza Lobo, "'Just bring me a little letter": the flow of things in Cape Verde transnational family relations", Etnográfica [Online], vol. 18 (3) | 2014, Online since 09 October 2014, connection on 11 February 2022. URL: http://journals.openedition.org/etnografica/3788 ; DOI: https://doi.org/ 10.4000/etnografica.3788

\section{(c) (i) (8)}

Etnográfica is licensed under a Creative Commons Attribution-NonCommercial 4.0 International License. 


\section{"Just bring me a little letter": the flow of things in Cape Verde transnational family relations}

\section{Andréa de Souza Lobo}

This article discusses the ways people strengthen and maintain their sense of belonging to concrete or imagined places or groups via communication networks. It focuses on the flow of things through transnational networks between Cape Verdean migrants and their relatives at home. It is an intense and diversified network involving kinship ties in a context of prolonged physical distance in both space and time. The flows in question consolidate social, cultural, and family networks between migrants and their home communities in a complex system of exchange and circulation of gifts, requests, money, and information that mobilize those who leave and those who stay. The argument is based on the dialogue between ethnographic data and works that have explored transnational flows of people, capital, and goods within the globalization framework.

KEYWORDS: Cape Verde, flows, migration, family, circulation, commodities.

"Só uma cartinha": o fluxo de coisas nas relações familiares transnacionais em Cabo Verde - O artigo trata das formas como as pessoas fortalecem e mantêm um sentido de pertencimento a lugares ou grupos, concretos ou imaginados, por meio de redes de comunicação. O foco recai nos fluxos de coisas em redes transnacionais formadas por migrantes cabo-verdianos e seus parentes que ficaram no país. Trata-se de uma rede intensa e diversificada que envolve relações de parentesco num contexto de distância física prolongada, tanto no espaço quanto no tempo. Os fluxos em questão consolidam laços sociais, culturais e familiares entre estes emigrantes e suas comunidades de origem, num complexo sistema de trocas e circulação de presentes, dinheiro e informações que mobilizam aqueles que partiram e aqueles que ficaram. O argumento se baseia num diálogo entre os dados etnográficos e estudos que exploram os fluxos transnacionais de pessoas, capital e bens.

PALAVRAS-CHAVE: Cabo Verde, fluxos, migração, família, circulação, mercadorias.

LOBO, Andréa de Souza (andreaslobo@yahoo.com.br) - Department of Anthropology, University of Brasilia (UnB), Brazil. 


\section{INTRODUCTION}

This article is about the ways people strengthen and maintain their sense of belonging to concrete or imagined places or groups via communication networks. ${ }^{1}$ It focuses on the flow of things through transnational networks between Cape Verdean migrants and their relatives at home. It is an intense and diversified network involving kinship ties in a context of prolonged physical distance in both space and time. To think about social relations from the vantage point of the flow of things leads us to ponder about the relationship between proximity and materiality in transnational contexts, creating new possibilities to think about forms and strategies put into play for maintenance and updating of kinship structures experienced from a distance.

I consider that the flows in question consolidate social, cultural, and family networks between migrants and their home communities in a complex system of exchange and circulation of gifts, requests, money, and information that mobilize those who leave and those who stay. My argument is based on the dialogue between my ethnographic data and works that have explored transnational flows of people, capital, and goods within the globalization framework. In establishing this dialogue I intend to contribute to the position according to which local communities, families, and individuals who stay home creatively interpret, negotiate, and interact in the context of global processes, often reproducing existing familial relations.

I thus present the argument that those who stay behind, the non-migrants, participate actively in migratory processes by creating a circuit for exchanging material goods, which encourage fulfillment of certain moral obligations by the migrants. This circuit, which sets the circulation of encomendas in motion, shortens distances in the way it keeps migrants close and present in kinship networks at the local community. ${ }^{2}$

Furthermore, discussions about the forms in which circulation of material objects between migrants and those who stayed behind play a role in construction and maintenance of social relations take me beyond a dialogue with contemporary transnational studies, to classical discussions in anthropology. Mauss, in his work about the nature of the gift, stated that exchange relations are moral relations, since "when we give something, we give a part of ourselves” (1974 [1923-24]: 202).

I An earlier version of this text was presented at the seminar "Places, People, and Groups: The Politics of Belonging in International Perspective", University of Brasilia, 25-26 November 2009. I thank the participants for their valuable suggestions. I am also grateful to my colleagues Alcida Rita Ramos and Wilson Trajano Filho for their reading of an earlier version and for their comments and contributions on this paper.

2 The word encomenda may comprehend a large list of objects that are sent to relatives or friends on a different island or in a different country. 
Although Mauss' thesis already introduces this complex matter of distinction between subject and object, as stated by Howell (1989), anthropological literature looked first at the role and nature of exchanges and exchange relations, and only recently did anthropologists dedicate their attention to the nature of objects exchanged and the relations between objects and the people who gave them. If this initial lack of interest can be attributed to an anthropological concern of not seeing people as mere objects (Sahlins 1976), in the past decades the relation between subject and object has been a topic dear to social science studies. These approaches are characterized mainly by the interest in understanding what things do in the world, how objects construct people and relations, as well as how people manufacture objects.

For my purposes in this study, the proposal by Appadurai (2008 [1986]) of breaking the dualism between gift and commodities is worthy of note in this context. In his influential introduction to the collection The Social Life of Things, the author not only returns the object commodity to the forefront of the subject, but also defends the study of commodities in a well-known logical framework, that of the kula (Malinowski 1976 [1922]). The author states that gift exchanges and commodities circulation can be analyzed in the same manner, since commodity has a spirit. He thus shows the importance of monitoring flows of goods in order to understand the different valuation regimes they are under while in movement through varying contexts. To complement his thesis statement, Kopytoff, in the same collection, presents the concept of "biography of things" (2008 [1986]), focusing on an analysis of things as cognitive and cultural processes, rather than just things that are produced, put into circulation and exchanged for money.

Dealing with transnational relations between Cape Verdeans who stay behind and those who emigrate from a standpoint of encomendas that circulate therefore allows us to demonstrate the dialectic relationship between goods and people by bringing back the Maussian maxim that exchange relations are moral relations. Additionally, the focus on things exchanged makes it possible for us to reflect on how goods in motion bring people together. This argument thus adds to these new analyses of objects as social constructors, as well as studies focusing on the simultaneous nature of lives lived within and outside the borders of the Nation-State, acknowledging that migrants are still highly influenced by their countries of origin through social networks across national boundaries.

I therefore present the argument, firstly, that flowing goods create simultaneity, since they engage individuals in day-to-day social and practical relations that overcome geographical frontiers (Levitt and Glick Schiller 2004). Secondly, I posit that this simultaneity is also valid for those who remain in the country of origin and are engaged on a daily basis in a social framework 
that cuts across borders. Not only those who migrate, but also those who stay behind can behave in a transnational manner. ${ }^{3}$

Although important in the context of circulation, remittances are not analyzed in this study because I am interested in the many directions of the flows of material goods. The studies about remittances show us one type of unidirectional flow - migrants sending money to non-migrants - and the asymmetry of relations between those who leave and those who stay (Åkesson 2011), making it necessary, in my opinion, to focus on flows which happen in other directions, understanding non-migrants not as mere addressees of financial stipends and messages, but as active participants in a universe of exchanges. The flow of encomendas seems to be a good way to address this issue.

Encomendas can mean anything from small parcels with souvenirs, cash, or photographs to suitcases and boxes filled with miscellaneous objects. Its traffic is part of local day-to-day life, and it is perfectly common for a traveler to be called upon at home or in the airport to be the bearer of these goods. Encomenda exchanges are, therefore, an effective means to be in touch. Given their importance, there are various strategies for circulating them, generating not only mutual recognition between those who give and those who receive, but also a set of tensions and expectations. These issues will be addressed later from analysis of ethnographic data and two Cape Verdean lyrics songs.

This study is based on fieldwork carried out on the Island of Boa Vista in 2004 and early 2005, when I carried out fieldwork among the people of Vila de Sal Rei on migratory flows and their influence on the transformations in the organization of local families from a standpoint of those who stayed behind. Boa Vista is one of ten islands that make up the Cape Verde archipelago, about 500 kilometers off the Atlantic coast of Africa. It is the third largest island in size, but the least populated, with 4,206 people (1,872 women and 2,334 men) spread out in eight settlements. The largest of these is Vila de Sal Rei that comprises over half of the total island population. In the national context, this island stands out due to an important migratory flow of women to Italy, where they work as housemaids (Lobo 2012).

An important part of my knowledge about the flow of material objects and information between migrants and non-migrants was acquired through participant observation. During my fieldwork I took part in the daily lives of seven families with more than one member in migration and which had in their contexts both situations in which these flows were constant and those in which

3 Most phenomena being described here have also been noted in other contexts, specifically the Caribbean. Nina Glick Schiller and Georges Fouron (2001), for example, have written about the movement of goods back and forth as demonstrating a sense of obligation and reciprocity among families in ways that reproduce normative social hierarchies in Haiti rather than transforming them. See also Richman (2008) and Olwig (2002). The case presented here joins this literature emphasizing how movement and flows are central to family consolidation. 
they were broken, consequently affecting relationships. In addition to participation in the daily routine of these families, I conducted over 50 open-ended interviews, visiting and befriending the inhabitants of more than 30 domestic units, all with migrant members. Between the months of July and September, 2004, I had the opportunity of interviewing, observing and following migrants returned home for vacations on the island, which broadened my perspective for analyzing their relationships with those who did not migrate. The intensive fieldwork, which took place over an extended period of time (15 months), thus made it possible for me to gain access to domestic units in different social strata, observing that the flows under analysis here and their importance are not restricted to so-called poor families, which enables exploration of different meanings of exchanges which are not connected with financial needs.

Lastly, it should be clarified that, even though the perspective of those who did not migrate is privileged, the argument presented here has the objective of bringing to the limelight flows in both directions, from migrants to non-migrants and vice-versa. Therefore, if a good part of the analysis is based on knowledge about those who stayed behind, I also present elements of the perspective of migrants whom I observed and interviewed, thus analyzing the different paths that objects and information take when being exchanged.

\section{PEOPLE IN FLUX}

In order to understand the dynamics of sending and receiving objects and information, it is important to know about the local forms of organizing the circulation of things and people in the local context. I have the same opinion as Gamburd, who says that "while one cannot elucidate local dynamics without reference to the global, there is an equally important but perhaps less obvious reciprocal truth: one cannot understand global structures and processes without reference to the local" (2008: 7). In fact, flows originating in sending countries depend on the family structures that facilitate them.

In the ethnographic case in question, we are faced with a family structure which has the following general characteristics: mobility of men, women and especially children among many domestic units as part of family dynamics; constant sharing of food and things among houses; the central units are strongly associated with women and children; men characteristically have relations marked by absence and distance from the daily lives of their children and their children's mothers, contributing financially and socially in a sporadic manner; many grown women emigrate, leaving behind family members, children and the fathers of their children on the island (Lobo 2011). ${ }^{4}$ 
The culture of migration in Cape Verde has been shaped across space and time. From discovery (1460) to nowadays, successive generations of Cape Verdeans have grown up seeing mobility as an intrinsic part of life. The flows of young males begun under Portuguese colonial rule, when Cape Verdeans were sent to the Guinea coast; later, around the middle of nineteenth century, a migration flow to the Americas developed. The beginning of the twentieth century is marked by a forced migration to other Portuguese colonies with varying degrees of coercion and by the closure of migration to the United States. At this time Cape Verdean migration to Europe gained pace - Portugal, Netherlands, Italy were the destinations. If, by then, the phenomenon was essentially masculine, since the 1960s there is a growing number of young women going out to places such as Italy.

Elsewhere (Lobo 2010, 2011, 2012) I have argued that the Cape Verde migratory context can be understood as both an individual and a family strategy. In the context of families, since they export some members, they actually reproduce themselves. Gender and generation solidarity is crucial to transforming seemingly disruptive situations into continuity. In a world of flux and displacement due to migration, family continuity is preserved with the creation of social spaces where the sense of belonging is reconstructed.

Many studies about the archipelago (Carling 2008; Åkesson 2004; Fikes 2009; Carter and Aulette 2009; Drotbohm 2009; Trajano Filho 2009; Dias 2004) have pointed out that a unique feature of Cape Verde's social structure is the outward flow of its members, reaching destinations far beyond its limits. We might say that people migrate because they need to be connected to those who stay home as a way to constitute themselves (Carling and Åkesson 2009). Cape Verdeans leave in order to construct their lives, their homes, and a better future. Monetary remittances, the sending of goods, visits, and the flow of things in general would represent a sort of material contextualization of affective ties, a fundamental strategy to maintain the sense of proximity, both for those who are away and for those at home.

For most people, especially young women, to have a better quality of life means to emigrate, a desire shared by the whole family. Going abroad is seen as the best way to achieve a qualitative change in their lives. As a family strategy, it is as important for those who stay as for those who leave.

Families share the dream and help the migrant by creating networks, helping with documentation such as visa requirements, and establishing contacts that might help the migrant find work and support in Italy (the destiny of most Boa Vista women). When she finds a regular job abroad, the migrant is expected to start helping her relatives by means of money orders, clothes, 
shoes, household utensils, and medicine. Besides increasing the family's income and raising their standard of living, the migrant's purpose is to save enough money to build a house where she can live and manage a small business from which to draw the money for her monthly expenses. To them having a house of their own is of utmost importance, and makes the effort of emigrating worthwhile.

In this sense, spatial distance does not necessarily slacken kinship ties. What really matters is that they all play out their roles as expected. I therefore understand that expectations related with the sending of resources and goods by migrants goes beyond economic aspects regarding improved quality of life, being part of a moral discourse about the type of attitude expected of a relative who migrated. Alexandre, a young man whose mother migrated several years before, emphasizes these aspects:

"At first it was difficult, I missed her a lot, but then I got used to it. My Mom's been in Italy since I was a little kid and I was raised by my relatives here in Boa Vista, but she's always been present in my life. Her sacrifice in Italy put me through college and I have a profession now thanks to her. Nothing was ever wanting, because she always sent me whatever she could. What I remember most about my childhood, however, is how good it felt to receive a gift from her. This brought us closer and I knew she hadn't forgotten about us."

According to this moral discourse, relationships between kin in Boa Vista must be acted out with sharing, otherwise relatives have nothing in common and kinship ties weaken. Unlike some studies which emphasize ruptures inherent in physical separation between close relatives and the emotional costs of separation (Hochschild 2002), I argue, based on cases such as Alexandre's, that the physical distance in itself does not loosen the ties between mothers and children, fathers and sons, or comrades; instead, neglecting to share does. Even in the context of emigration, if relatives succeed in creating and recreating interactive relationships, providing care and affection through mutual exchanges, that is, if they build a common base, their relationship is kept strong. Along the same lines as this argument, the rupture takes place when what is expected from someone is not fulfilled, leading to a process of deconstruction of the person's value expressed by words such as ingratidão (ingratitude) and abandono (abandonment). ${ }^{5}$

5 We cannot forget that there are those that are "forgotten" back home either because the emigrants don't have the means or they cut ties because they no longer plan to return upon retirement, occasionally setting up a second family in the receiving country. 


\section{THINGS AND RELATIONSHIPS}

Dia que bô bá pa Cabo Verde

bô perguntam

O quê cum cria dalá pa bô trazem

Oiá um pergunta que bô ta fazem

Bô crê sabê o quê cum crê pa bô trazem

Oiá um pergunta que bô ta fazem

Bô crê sabê o quê cum crê de nha terra

Trazem só um cartinha

Pa ca pesá na bô mala

Trazem só um cartinha

Ma dôs regrinha

Ma naquel cartinha trazem Morabeza

Naquel cartinha trazem um Serenata

Ma naquel cartinha trazem nha crêtcheu

Naquel cartinha trazem tude

quel Mar Azul

(Só Um Cartinha;

letra e música de Lura)

Oh Naia

Kuse ki'n fazeu

Só pamodi n’ba Lisboa

Ma nada n'ka trazeu

A mi n'cumpra tlivison

Ku video ku DVD

Computador pa nha fidjo

Boneca pa nha côdé

Nha dona pidim keli

Nha pai dja pidim kelá

Nha guenti mó ki'n ta fazi

Sem dinheiro ka ta da

Na frontera: 'Senhora tem muito peso

Tem que pagar este excesso'

Dinheiro gó kem ki fla?
The day you went to Cape Verde you asked me

what I wanted you to bring me from there

what a question to ask

you want to know what I want you

to bring me

what a question to ask

do you want to know what I want from home

just bring me a little letter

so as not to weigh in your suitcase

just bring me a little letter

and some news

but in this little letter bring me morabeza in this little letter bring me a serenade but in this little letter bring me my love in this little letter bring me all that blue sea.

(Just a Little Letter;

lyrics and tune by Lura)

Oh Naia

What have I done to you?

Just because I went to Lisbon

And brought you nothing

I bought a TV set

With video and DVD

A computer for my son

A doll for my youngest

My grandma asked me for this

My father asked me for that

Oh dear, what shall I do?

With no money, no way!

On the border: 'Lady, you have too

much weight.

Have to pay excess'

Money, who says I have it? 
N’papia kuel sô na badiu

Minina n'dal sô pa dôdu

Ê fla: 'Senhora já viu que

Não tenho o dia todo?'

Oh Naia

Kuse ki'n fazeu

Só pamodi n'ba Lisboa

Ma nada n'ka trazeu
I spoke to him only in badiu

Baby, I pretended I didn't understand

He said: 'Lady, can you see

I don't have all day?'

Oh Naia

What have I done to you

Just because I went to Lisbon

And brought you nothing

(Oh Naia; letra e música de Lura)

(Oh Naia; lyrics and tune by Lura)

Popular culture in and about the archipelago gives us a proper dimension of what emigration means to Cape Verdeans and the storm of ambivalent feelings it triggers: longing, sadness, adventure, hope, sacrifice, joy. A recurring theme in Cape Verde music ${ }^{6}$ and literary genres is the dilemma between leaving and staying. Lura's ${ }^{7}$ lyrics above synthesize and strengthen some of the aspects analyzed here. Interesting to say that Lura lived most part of her life as an emigrant in Portugal and now, as a famous singer, moves between the two countries.

Taken together, the songs point at the direction of the flows. From the migrant's point of view, the first lyrics focus on the yearning she feels for her home country and the opportunity to ease this feeling through a messenger who offers to take an encomenda, a little letter. In the second song we have an implicit dialogue between Naia and a hypothetical migrant. It is about the predicament of someone who returns to Cape Verde from Europe, demands for goods, and the practical problems of meeting all of them. Naia's frustration for not having been contemplated with the goods brought home from Lisbon illustrates the expectations of those back home with regard to the consumption of symbols of modernity through those who circulate between two worlds.

The song also addresses the issue of quality. If, on the one hand, all the migrant wants is "just a little letter" talking about morabeza, her love, serenades, and blue sea, on the other, she must send home a DVD, a computer, a TV set. The flow of goods is a two-way affair conveying specific things, symbols, and signs of two worlds connected by the migrants as mediators between Cape Verde and the outside world. They reinvent not only the vision of the Islanders about that world, but also promote Cape Verde vis-à-vis other places.

6 Dias (2004) analyses the morna and coladeira music genres and their connections with the theme of emigration and Cape Verdean identity formation.

7 Lura, born on July 31, 1975, in Lisbon, is a singer/songwriter of Cape Verdean ascent who had her career boosted in the mid 1990s after recording her first album, Nha Vida. Since then, the artist has stood out in the Cape Verdean music scene, singing about everyday life in the islands, in Creole. 
Both sides send encomendas. Unlike what we know from reports on flows in migratory contexts, in Cape Verde sending encomendas, rather than a unilateral obligation on the part of the migrant, is also a duty on the part of relatives and friends on the islands, thus generating a circular movement fed by reciprocity between people who are apart. For those who stay, sending encomendas is also part of the catalog of actions that confer reciprocity. Let us analyze this circuit a little more closely in the two topics below.

\section{Flows originating in Boa Vista}

The economic importance of flows of goods, money, and news between migrants and their communities of origin is evident. However, this is not the only reason why anthropologists have been studying them more frequently, perceiving them as apt instruments for the analysis of cooperative relations and the construction of identities and belonging. Here the concepts of reciprocity and responsibility are basic to understand the various timings, rhythms, and meanings of the present-day worldwide migratory circuit (Rosaldo and Inda 2008). Equally important are the spaces of tensions, negotiations, and decision-making which are generated by these exchanges and nourish feelings of belonging in the participants. All these spaces, mediated by increasingly efficient technologies of communication, play a central role in "shortening" the physical and temporal distance between the migrants and those on the island.

The case analyzed here, however, allows us to further explore this argument, making it possible to follow the transit of objects in a direction different from the goods sent by migrants, that of objects sent by those who stayed in the community of origin. Looking at this aspect of the relation between materiality and proximity enables us to go beyond the statement that sending things strengthens family relations experienced from a distance and to question the paths these exchanged things take, as well as quantitative and qualitative aspects of these exchanges, which vary according to the social stratum and the position of the people involved regarding gender, age and geographical position.

Thus, it is necessary to explore the transit of encomendas from those who stayed to those no estrangeiro (abroad). The following account gives us an idea of this practice:

“- So, I'll be heading out now because I have to stop by the market to get two cans of tuna fish.

- Are you cooking dinner tonight?

- No, Maria's leaving for Italy early tomorrow morning and I'm sending an encomenda for my sister, who's bound to be happy to get a little something from home to cheer her up from all the sacrifice she's living in their land. You know I sent tuna a little while back to my cousin and 
a few days later she called me up to thank me and said that that can of tuna made a lot of people happy, because she prepared a 'tuna rice' ${ }^{8}$ at her place, and one thing led to another, and before they knew it they had a full-blown party going. Everyone was there eating, dancing like they were back here in Boa Vista. I was so happy to hear that I made my cousin happy, because whenever she can, she sends me a little something from over there!"

This is an excerpt from my field log, which portrays the end of a conversation with an interviewee who paid me a visit. In her speech some important characteristics of this encomenda circuit are expressed: the meaning of what is being sent, its quality, expectations regarding the addressee and reciprocity. Thus the importance of the quality of the things sent. The encomenda sent by Maria is a sign of affection and connection. Like the lyrics to the song that lends its title to this article, goods circulating between Cape Verde and diaspora countries create a circuit that feeds into not only a feeling of belonging, but also emphasizes the importance of an individual migratory project for a greater collective group, be it the family or the country.

If these dimensions are expressed upon sending a present to a relative that left, the words of a migrant I interviewed express the importance of encomendas received.

"On our days off in Italy we usually get together, get something to eat, and hang out. If there are any encomendas from Boa Vista, it fills us with joy! We feel at home, make catchupa, stew and other local foods, we speak Creole and catch up on our gossip from home. In summary, it's a day when we feel close to Cape Verde. Without these days, I couldn't take that life, it would drive me insane!"

Whenever possible, family and friends make small packages with notes that identify the sender and the receiver, and a few words saying how they miss the person and how they look forward to an encounter. Those who are away attribute to these encomendas the function of soothing their yearning and always receive them warmly. Any sign that connects them to their home country is welcome to nourish their sense of belonging and maintain proximity.

Local people are expected to send the so-called "things from the homeland:" goat cheese, grog (sugarcane liquor), punch (an Island traditional drink), cookies, bread, dried fish, seafood (especially lobsters), canned tuna, and traditional sweets. The products and respective amounts sent are analyzed later, for now it 
should suffice to say that, from a standpoint of those who stay, migrants expect to receive products which remind them of Cape Verde and the family members who stayed behind. Therefore, products made by the senders themselves are highly valued. Lastly, photographs of family members are precious gifts since they strengthen the feeling of simultaneity (Levitt and Glick Schiller 2004).

Senders expect encomendas to serve the function of reducing the longing caused by the distance, being received as a token of love and encouraging reciprocity between sender and recipient. The next step involves an inversion of the direction of the exchange, also changing the quality of what is exchanged. At this moment, whoever sent expects to receive something of value which represents the other person's world. In exchange for the mementos from home, they expect to receive "things from the world out there".

\section{Migrants' presents}

Supporting family members is expected of a relative. This support is expressed by the word ajuda (assistance) and takes on different meanings according to the role played by each of its members. The idea of ajuda therefore includes a set of mutual obligations that reflect moral ideas of what is expected of a relative. These expectations are at stake on a daily basis and are important in the definition of a person as "someone who is reliable" or someone who is responsible or not. In the case of migrants, the meanings of proximity or distance are connected with the sending of material goods, be they in the form of money or objects. Those who stay, in turn, can provide support to those who left in different forms, which go beyond sending things.

Therefore, if encomendas exchanged in either direction have their value established according to scarcity, i.e., on both sides people receive objects which cannot be easily found where they live, on the other hand, a difference in meaning can be observed between what is sent by locals and the presents sent by migrants. Encomendas sent by those who stay express love and longing and kindle social spaces of belonging by means of sharing. With this, they serve the function of approximation, of shortening distances. For those who stay, social spaces for construction of ajuda are not directly associated with sending "things from home", the assistance expected of them is in raising a migrant's child, caring for elderly parents, or lending a helping hand in the construction of a house.

Every once in a while, migrants also have the opportunity to meet their obligations not by sending encomendas, but, for instance, by making possible migration of a family member or making frequent phone calls. Nevertheless, it is financial remittances and sending of things that best translate ajuda. The support given is therefore expressed by materiality and it is by means of this materiality that relationships are maintained, generating a set of expectations regarding frequency, quantity, and quality of objects. Goods sent by migrants 
are therefore closer to the definitions attributed to financial remittances, i.e., "underline the moral demand on the migrants to support other family members" (Åkesson 201 1: 149).

Sending of goods by migrants is, therefore, a constant reason for tension in the family since it implies an assessment of the quality of this relationship. Conflicts derive from expectations of different members and it is up to migrants to evaluate and respond to demands in a balanced manner. The first variable which affects this balance is the frequency with which goods are sent, so, a migrant who sends nothing for a long period of time, not even news, is described by using words such as forgotten, ingratitude and abandonment. Linda's case is illustrative of this type of situation:

"My mother has been in Italy since I was five years old. In the beginning, she used to send money, gifts, she called often and came down on her vacations every two years. But over time, she started forgetting us and forgetting all the promises she made when she left. My grandparents helped cut through the red tape to get her papers and she said she would help them expand their house, that I would study abroad and a bunch of other stuff. If you ask me which of these promises she kept, I'll tell you: she didn't keep a single promise, she is an ingrate! When I look at my cousins and friends, whose mothers send pretty clothes and shoes from Italy, I feel abandoned. But I'm used to it now, I don't even miss her anymore! She is someone I don't even know and for whom I have no feelings!"9

Not meeting what is understood as an obligation between family members is similar to a rupture which leads to a negative evaluation of the other. In Linda's account, the interruption in the flow of goods results in a rupture in the mother-daughter bonds. These ruptures reflect not only the interruption in Linda's access to the goods which the mother's migration would provide - pretty clothes and shoes from Italy - but also an interruption in the flows of affection and attention which keep alive the relationship between the two, in spite of the distance. A break in the flow of material goods is what leads to a loss in the quality of the relationship.

Linda's account therefore brings us to my central argument here. This argument does not imply that people do not miss those who left or do not experience pain and longing, but the forms in which relationships at a distance are experienced in Cape Verde allows us to remove ourselves from some analyses that seem to be based on the idea that those affected need physical proximity in order to feel close. I am referring to studies that overly emphasize 
separation of mother and children as something negative, dysfunctional, and morally wrong, presenting the argument that emotional, social, and psychological costs of this separation are too high (Hochschild 2002; Parreñas 2005; Gamburd 2008). I believe the case in question may be constituted as an alternative to this type of analysis, considering that continuities and ruptures are seen in a different light, based on the perspectives of the subjects themselves.

In addition to frequency, what the migrants send is as important as the sending itself. To be remembered is a central value expressed in the act of sending a gift, but the quality and quantity of what is sent is a sign of status for both donors and receivers. ${ }^{10}$ I frequently observed unfulfilled demands generating accusations of stinginess and ingratitude. By way of illustration, let us see one such case.

In one of my late afternoon visits, I stopped at Nhá Tina's. While we talked, the phone rang. It was her daughter Julinha. She was calling from Italy to say she had sent some boxes on a boat scheduled to arrive in Boa Vista the following week. The news rapidly spread out to the whole family. Fifteen years earlier, Julinha left for Italy and put her two daughters (Diana and Rô) in Nhá Tina's care. They too were eager to hear from their mother. Two weeks later, I heard that a boat had just arrived from Italy and went back to Nhá Tina's house, curious to know about the encomendas. Julinha had sent clothes, mostly second-hand, some non-perishable foods (coffee, chocolate, canned items), cleaning products for the house, and toiletries. Diana and Rô were disappointed with what they got, showed me the clothes and perfumes, and said: "Just look at this, Julinha always sends poor quality things. We find this stuff in the Chinese store, right here in Boa Vista; she didn't have to send it all the way from Italy!"

The relationship between the quality of goods sent and the quality of the relationship is made clear here, at least concerning the relationship between migrant mothers and their children who stay behind. From the perspective of children, having a migrated mother means sacrifices, longing, and pain from the distance, but it also means the possibility of a set of goods which symbolize modern times and status.

There is the expectation that those who are away, usually in European or American cities, should send money and goods from these places: clothes, shoes, fashionable ornaments, medicines, non-perishable foods, and electronic gadgets. As in Lura's lyrics of Oh Naia, they ask for items that are lacking in Cape Verde and are typical of the much prized modernity and fashion of the world at large. Particularly in the case of migrants' children, the most

10 It is worthwhile to compare the Cape Verde case with that studied by Lisa Cliggett (2005) focusing on the exchange of goods in Zambia migrations, in which value is placed on the exchange process rather than on the quality of the gift. 
valued items are cell phones, electronic games, computers, clothes and shoes by famous makers.

Thus, gifts and encomendas are mandatory in such contexts and women are in part evaluated for how much, what, and how often they send gifts to their relatives. Therefore, the migrants usually try to reach a balance that preserves family relationships.

One of the ways to reach the balance mentioned above is sharing information about the world they live in. Gone are the days in which those who stayed knew nothing about the life of migrants in their destinations. New communication technologies became allies in approximation of these two worlds, facilitating access to knowledge and more intense exchanges of information between these two poles. If, on the one hand this proximity brought more demands for migrants, on the other hand it enables these migrants to expose their difficulties and justify the occasional absence. For those who remain on the island, these absences are explained by means of a perception that migrants lead a life of sacrificio (sacrifice) in Italy and by the common belief that "life abroad is an illusion". These two perspectives are often called upon by migrants during telephone calls and vacation visits, both made easier by the increasing access to means of communication and transportation characteristic of the past decades.

An analysis of a transnational circuit of exchanges of objects, information and affection, adds to the complexity of a simple reality for those who uncritically accept the notion that what motivates people to emigrate is no more than the wish to have a more comfortable life and a higher social status.

Some scholars (Hannerz 1997; Glick Schiller, Basch and Blanc-Szanton 1992; Ribeiro 1997) who also disagree with this simplistic view become associated with an idea of transnationality that questions the correlation between territories and the various socio-cultural and political arrangements that guide people in their representations of membership in socio-cultural, political, and economic units. In contexts of migration, transnationalism can be defined as a set of symbolic and material processes in which migrants build and maintain multiple relations that connect various points of their mobile lives. We can only interpret this issue properly if we abandon the traditional opposition between "society of origin" and "society of arrival".

In emphasizing the immigrants' experience and the relations they build in the new place, this position offers a more sophisticated way to approach the complex articulations between the place of departure and that of arrival created by migration (Glick Schiller, Basch and Blanc-Szanton 1992: 2). It also shifts the focus from economic considerations as the main driving force in migratory flows.

In this context, we have interesting researches that have been carried out on the sending societies and the role of remittances, including goods, for family 
left behind. Since Stuart Philpott's seminal work on the social fields of relations connecting family in the Caribbean and migrants in the UK (see for example Philpott 1968, 1973), a large number of studies of Caribbean migration have looked at exchange relations, including the goods they may involve, from the perspective of both migrants and their family in the society of origin. They have also paid attention to the ways in which these exchanges shape, and are shaped by, the obligations and expectations inherent in family relations, and some of the conflicts that may emerge from the dispersal of family members.

The Cape Verde case permits us to incorporate more ethnographic data concerning the ways in which flowing goods create simultaneity by engaging individuals in day-to-day social and practical relations which overcome geographical frontiers, with particular focus on how this applies to those who remain in the country of origin and are engaged on a daily basis in a social framework which cuts across borders.

Nevertheless, when I include the Cape Verde case in this debate, I defend that, rather than producing a time-space compression (Harvey 1989) or a distance in time and space (Giddens 1990), the global flows that encompass Cape Verdean society burden the migrants' communities with growing duties and create contexts of negotiations linking kin and kith back home. This process no doubt generates values, but it mostly maintains values, in a movement that contributes to the reproduction of social relations. Thus, the sense of belonging resides in the quality of social relationships at a distance rather than in their permanent sharing of the same space. In fact, distance contributes to preserving patterns of the local organization in the context of increasing mobility.

\section{CLOSING COMMENTS}

Initially, classical literature about relations between migrants and non-migrants focused on understanding realities and perspectives of the former, leaving a gap in the experiences of those who stay and their communities of origin. Upon diagnosing the need for information about this universe, researchers have been producing interesting studies about non-migrants (Riak Akuei 2005; Glick Schiller and Fouron 2001; Åkesson 2011; Levitt and Glick Schiller 2004). Nevertheless, the resulting image shifts between supporters of migrants and future or former migrants. My experiences in Cape Verde, however, painted a more complex picture and this study points to some dialogue with the efforts of other authors to develop nuanced approaches to issues of transnationalism and social solidarity.

First, I posited that non-migrant Cape Verdeans are not mere receivers or supporters of those who chose to live their lives abroad; they play an active role in the complex circuit of material goods which construct relations of 
proximity between those who left and those who stayed. Thus, those who stay do not experience transnationality only in an indirect manner, which makes it necessary for us to redefine the boundaries of social life not only for so-called transmigrants (Glick Schiller, Basch and Blanc-Szanton 1992), but also for non-migrants who become engaged in social and practical relationships which cut across borders.

Second, unlike the ideal type in which the emotional component of interpersonal relations is more important than material transactions, Cape Verdeans characterize their relations in terms of the kinds of material transactions: who gave what to whom in what circumstances. The value placed on exchanging and sharing goods defines the quality of the transnational relations. In this context, separation would be "minimized" by the rationale of material obligations; there would be a tendency to qualify social relations in terms of an idiom of material transactions.

It is worth noticing that some contemporary authors, as they cast a new look at material culture and the role of objects in the field of social relations in modernity, bring out new theoretical and methodological frameworks to observe how objects flow in various societies. As mentioned at the start of this study, we have, for instance, a study of the social life of things (Appadurai 2008 [1986]), of their biographies (Kopytoff 2008 [1986]), and their central role in producing social relationships (Miller and Slater 2002; Miller 2010).

Daniel Miller (2010) explores some interesting dimensions in ethnographic studies in Trinidad, India, and London with the purpose of challenging our perception that things and people are in opposed universes. The materialization of relationships, therefore, does not seem to be a unique African trait as opposed to the West, as Levine argues in his controversial study of patterns of personality in Africa (1973), but it is also found in the West, according to Miller and others. Sahlins (2000) adds to the debate when he analyses the exchange processes and the "indigenization" of Western goods by Pacific peoples. In the context of migrations where material goods and money circulate around the globe, he says: "Today, the huge phenomenon of circular migration is creating a new kind of cultural formation: a determinate community without entity, extending transculturally and often transnationally from a rural center in the Third World to 'homes abroad' in the metropolis, the whole united by the to and fro of goods, ideas, and people on the move" (Sahlins 2000: 522). "This flow of money and goods is better understood by the norms of "reciprocity" (2000: 523). In this sense, what appears as remittances and payments is simply the material dimension of the circulation of persons and concerns between local homes and others elsewhere.

In the Cape Verdean case, the continuity of material obligations in the context of emigration, in a circuit that involves both the migrants and those who stay home, acts as a bridge that shortcuts physical distance whether in 
space or in time. In this sense, circulating material goods are valued as constructors of relations and of proximity. The norms and notions that guide rights and duties between relatives are decisive for the operation of new ways of being close. When we analyze goods exchange, we notice the mediated character of this equation, namely, to achieve proximity at a distance, those involved use artifacts, people, and strategies that work as links in their circuit of relations.

Relationships between migrants and those who stay on the Cape Verde islands show that "being together" goes well beyond daily conviviality. This "being together" is maintained by fulfilling a series of duties and mediations, even from afar. The constraining factor is not physical and spatial distance, but the impossibility of sharing substances and experience. Thus, material flows have a strategic place as they contribute not only to the material reproduction of those who stay behind, but also to the cultural and symbolic reproduction of social relations. In this process, not only money and goods circulate intensely, but also the production and reproduction of cultural relations, collective identities, family and symbolic systems, and the sense of belonging.

\section{REFERENCES}

ÅKESSON, Lisa, 2004, Making a Life: Meanings of Migration in Cape Verde. Gothenburg, University of Gothenburg, doctoral thesis in Social Anthropology.

ÅKESSON, Lisa, 2011 , "Cape Verdean notions of migrant remittances", Cadernos de Estudos Africanos, 20: 137-159.

APPADURAI, Arjun, 2008 [1986], The Social Life of Things. Cambridge and New York, Cambridge University Press.

CARLING, Jørgen, 2008, “Interrogating remittances: core questions for deeper insight and better policies", in S. Castles and R.D. Wise (eds.), Migration and Development: Perspectives from the South. Geneva, International Organization for Migration, 43-64.

CARLING, Jørgen, and Lisa ÅKESSON, 2009, "Mobility at the heart of a nation: patterns and meanings of Cape Verdean migration", International Migration, 47 (3): 123-155.

CARTER, Katherine, and Judy AUleTte, 2009, Cape Verdean Women and Globalization: The Politics of Gender, Culture and Resistance. New York, Palgrave Macmillan.

CLIGGETT, Lisa, 2005, "Remitting the gift: Zambian mobility and anthropological insights for migration studies", Population, Space and Place, 1 1: 35-48.

DIAS, Juliana Braz, 2004, Mornas e Coladeiras de Cabo Verde: Versões Musicais de Uma Nação. Brasilia, University of Brasilia, doctoral dissertation.

DROTBOHM, Heike, 2009, "Horizons of long-distance intimacies: reciprocity, contribution and disjuncture in Cape Verde”, History of the Family, 14: 132-149. 
FIKES, Kesha, 2009, Managing African Portugal: The Citizen-Migrant Distinction. Durham, NC, and London, Duke University Press.

GAMBURD, M.R., 2008, "Milk teeth and jet planes: kin relations in families of Sri Lanka's transnational domestic servants", City \& Society, 20: 5-31.

GIDDENS, Anthony, 1990, The Consequences of Modernity. Stanford, CA, Stanford University Press.

GLICK SCHILLER, Nina, Linda BASCH, and Cristina BLANC-SZANTON, 1992, "Transnationalism: a new analytic framework for understanding migration”, in N. Glick Schiller, L. Basch and C. Blanc-Szanton (eds.), Towards a Transnational Perspective on Migration: Race, Class, Ethnicity and Nationalism Reconsidered. New York, New York Academy of Sciences, $1-24$.

GLICK SCHILLER, Nina, and Georges Eugene FOURON, 2001, Georges Woke Up Laughing: Long-Distance Nationalism and the Search of Home. Durham, NC, and London, Duke University Press.

HANNERZ, Ulf, 1997, "Fluxos, fronteiras, híbridos: palavras-chave da antropologia transnacional", Mana, 3 (1): 7-39.

HARVEY, David, 1989, The Condition of Postmodernity. Oxford, Blackwell.

HOCHSCHILD, Arlie Russell, 2002, "Love and gold", in B. Ehrenreich and A. R. Hochschild (eds.), Global Woman: Nannies, Maids, and Sex Workers in the New Economy. New York, Henry Holt and Company, 15-30.

HOWELL, Signe, 1989, "Adoption of the unrelated child: some challenges to the anthropological study of kinship", Annual Review of Anthropology, 38: 149-166.

KOPYTOFF, Igor, 2008 [1986], "The cultural biography of things: commoditization as process”, in Arjun Appadurai (ed.), The Social Life of Things. Cambridge and New York, Cambridge University Press.

LEVINE, Robert A., 1973, "Patterns of personality in Africa", Ethos, 1 (2): 123-152.

LEVITT, Peggy, and Nina GLICK SCHILLER, 2004, "Conceptualizing simultaneity: a transnational social field perspective on society", International Migration Review, 38 (3): 10021039 .

LOBO, Andréa de Souza, 2010, "Um filho para duas mães? Notas sobre a maternidade em Cabo Verde", Revista de Antropologia, 53: 11 17-146.

LOBO, Andréa de Souza, 2011 , "Making families: child mobility and familiar organization in Cape Verde", Vibrant, 8 (2): 197-219.

LOBO, Andréa de Souza, 2012, Tão Longe Tão Perto: Famílias e "Movimentos" na Ilha da Boa Vista de Cabo Verde. Cidade da Praia, Edições UniCV.

MALINOWSKY, Bronislaw, 1976 [1922], Argonautas do Pacífico Ocidental. São Paulo, Editora Abril Cultural.

MAUSS, Marcel, 1974 [1923-24], "Ensaio sobre a dádiva: forma e razão da troca nas sociedades arcaicas", in Marcel Mauss, Sociologia e Antropologia, vol. II. São Paulo, Edusp, 183-314.

MILLER, Daniel, 2010, Stuff. Cambridge, Polity Press.

MILLER, Daniel, and Don SLATER, 2002, "Relationships", in Kelly Askew and Richard R. Wlik (eds.), The Anthropology of Media: A Reader. London, Blackwell, 187-209.

OLWIG, Karen Fog, 2002, "Narratives of the children left behind: home and identity in globalized Caribbean families”, Journal of Ethnic and Migration Studies, 25 (2): 267 284. 
PARREÑAS, Rhacel Salazar, 2005, Children of Global Migration: Transnational Families and Gendered Woes. Stanford, CA, Stanford University Press.

PHILPOTT, Stuart B., 1968, "Remittances obligations, social networks and choice among Montserratian migrants in Britain”, Man, 3 (3): 465-476.

PHILPOTT, Stuart B., 1973, West Indian Migration: The Monserrat Case. London, Athlone.

RIAK AKUEI, Stephanie, 2005, "Remittances as unforeseen burdens: the livelihoods and social obligations of Sudanese refugees", Global Migration Perspectives, 20: 23-45.

RIBEIRO, Gustavo Lins, 1997, A Condição da Transnacionalidade. Brasilia, Anthropology Department of the University of Brasilia, series Antropologia, n. ${ }^{\circ} 22$.

RICHMAN, Karen, 2008, Migration and Voudou. Gainesville, University Press of Florida.

ROSALDO, Renato, and Jonathan Xavier INDA, 2008, “Tracking global flows”, in R. Rosaldo and J.X. Inda (eds.), The Anthropology of Globalization: A Reader. London, Blackwell, 3-47. SAHLINS, Marshall, 1976, Culture and Practical Reason. Chicago, The University of Chicago Press.

SAHLINS, Marshall, 2000, Culture in Practice: Selected Essays. New York, Zone Books.

TRAJANO FILHO, Wilson, 2009, "The conservative aspects of a centripetal diaspora: the case of the Cape Verdean Tabancas", Africa, 79 (4): 520-542. 